\title{
Improving the story-telling skill of grade 1 students through the use of hand puppet media
}

\author{
Siti Zuraidah *, Kastam Syamsi, Ashadi Ashadi \\ Universitas Negeri Yogyakarta. Jalan Colombo No.1, Yogyakarta 55281, Indonesia \\ * Corresponding Author. E-mail: zuraidasapen@gmail.com
}

Received: 10 August 2020; Revised: 13 August 2020; Accepted: 25 August 2020

\begin{abstract}
The purpose of this study is to improve the storytelling skills in language learning of grade I students of Muhammadiyah Elementary School Sapen Yogyakarta using hand puppet media. This research is collaborative classroom action research with the cycle model design. The subject of the study was grade I students of Al Ibadi Muhammadiyah Elementary School Sapen, totaling 30 students, consisting of 16 male and 14 female students. The data were collected through observation and documentation as well as using a questionnaire and test, and analyzed using the descriptive qualitative and quantitative analysis. The results show that the use of hand puppet media in Indonesian language learning could improve the storytelling skill of grade 1 students. This is evidenced by the increase in the students' average score and minimum mastery in their storytelling skills. The students' mean score increased from 62 in Cycle 1 to 80 in Cycle 2. Likewise, the percentage of the students with minimum mastery increased from $40 \%$ (12 students) in Cycle 1 to $87 \%$ (26 students) in Cycle 2.
\end{abstract}

Keywords: hand puppet, storytelling, media

How to Cite: Zuraidah, S., Syamsi, K., \& Ashadi, A. (2020). Improving the story-telling skill of grade 1 students through the use of hand puppet media. Jurnal Prima Edukasia, 8(2), 166176. doi:https://doi.org/10.21831/jpe.v8i2.33831

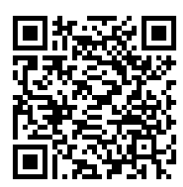

\section{Introduction}

Communication activities in language education, including local language, Indonesian, and foreign language, covers four skills to learn: listening, speaking, reading, and writing. These four skills must be developed since early ages. Through the teaching of language, the students are expected to be able to communicate well, both orally and in writing. Speaking skill is the language skill which is active and productive, which requires encoding, and which is the activity of using language to other people orally (Nurgiyantoro, 1988, p. 397).

One form of language competence activities is the storytelling activity. Story telling is one of the habits which have belonged to and developed in the society from then up to now. It is the speaking skill which aims to give information to other people. It is one of the important skills for children because it can inspire other children to be creative and it is useful for developing communication skill (Dunlap, 2009; Hong, 2012).

Problems in storytelling are experienced by grade I students of Muhammadiyah Elementary School Sapen. When asked to tell a story, they pointed to each other so that other students perform storytelling. This results in their low storytelling skill. The result of their storytelling assessment conducted by the researcher on March 8, 2018 shows that only eight students (27\%) out of 30 students have met the minimum mastery score of 75 in storytelling. The indicators of success in storytelling include pronunciation, intonation, body movement, and mimic. This result is in line with the observation conducted during the early teaching process, which showed that grade I students could not introduce themselves well, and some could express only one or two sentences. The story they told was also incoherent. Some students still had difficulties and could not tell story very well.

Developing the storytelling skill in language teaching requires teachers' patience because few students of elementary school are brave to do storytelling performances. The storytelling skill needs improvement because in practice it needs to consider the elements including pronunciation, voice, facial 
expression, performance, and appreciation. In addition, there needs to be supporting elements in storytelling, such as performance aid and media.

Hand puppets are one of the media for developing students' interest in order that they want and be brave to tell stories so that their storytelling skill improves. They are artificial objects in the form of human and/or animal. They are used as teaching media by way of playing them in a performance (Daryanto, 2013,p. 33). They are very much used in dramas which tell real life stories or for imagination. They are used by children for expressing what they have in their mind. They motivate children to use language (Nurbianti, 2005).

Hand puppets are puppets made of pabrics formed to resemble the face and body of different forms with various characters, which are played by using hands and by moving them by using fingers. They are also the media which can make children imagine and they can make children have a strong interest. They become props which are considered close to the naturality of storytelling (Musfiroh, 2008, p. 128). They can improve children's abilities in various aspects, including cognition, emotion, and social relationship. They facilitate teaching processes (Remer \& Tzuriel, 2015, p. 356; Sadiku, 2015).

In addition, hand puppets facilitate the process of dialogue and communication with $4-6$ year old children. By using hand puppets, the children can respond to questions very well. In this way, hand puppets become the media or tools for encoding messages in interviews with children (Petersen, 2014). Based on the above arguments, the researcher formulated the research problem as follows: What is the effort to improve the storytelling skill of grade I students by using hand puppet media.

\section{Method}

This research is collaborative classroom action research which is conducted in cycles. Classroom action research (CAR) is the research conducted in the classroom when teaching is in process. CAR is conducted with the aim of improving or increasing teaching quality (Warso, 2017). Classroom action research is conducted based on the problems in teaching processes, which needs the handling of a problem solution. It is conducted in collaboration between a researcher and teachers. In its implementation, the teachers act as observers and the researchers as the teaching executers.

This research was conducted at year 1 class of Al Ibadi, Muhammadiyah Elementary School Sapen, Bimokurdo Street No. 33, Yogyakarta. It was conducted in the first semester of the academic year of 2018/2019 from October to November. The research implementation was adjusted to the schedule of the Bahasa Indonesia theme for year 1 class of Al Ibadi. The subject of this research is grade I students of Al Ibadi class of Muhammadiyah Elementary School Sapen in their first semester of the academic year of 2018/2019, totalling 30 students, consisting of 16 male and 14 female students.

This research was designed to be in cycles. The model of the cycle followed that of Kemmis and McTaggart model, which is known as the cycle system. In one cycle, there is a cycle of activities consisting of planning, action, observation, and reflection. When Cycle 1 is almost over, and the researcher still finds shortcomings after the reflection, the researcher can continue to Cycle 2, which is with the same problem but with a different technique. Each Cycle 1s conducted in two meetings.

Before Cycle 1 was implemented, there were some activities related to it. Those activities included: (1) preparing the lesson plans for Cycle 1, whose theme was 'My Family', which was related to daily home activities; (2) preparing hand puppets to use; (3) preparing a video camera and a camera; (4) preparing an observation sheet and questionnaires for students and teachers; (5) discussion and coordination with school principal and observer teacher; and (6) preparing equipment related to the research.

During the teaching implementation in each cycle, the teacher and observer teacher did observation of both the students and teacher. In the teaching process, it could be seen that the students began to be active talking when the teacher told stories using hand puppets. Furthermore, the researcher saw the observation result obtained from the assessment of students' storytelling skill and from looking at the performance result through storytelling assessment rubric.

The researcher and observer teacher discussed the observation result during the teaching, such as the observation of the teaching process, the problems that happened, and all that were related to the action conducted, and then made improvement. Research instruments become the instruments used by researchers in the process of data collection in order to help the data collection activity, so that the data obtained are exhaustive, systematic, and easy to analyze (Arikunto, 2005). The instrument used in this 
research is an observation sheet for observing the process of teaching done by the teacher and the students' storytelling skill.

The instrument grids used with the storytelling skill variable include the sub-variable of expressing in general, and expressing ideas. The indicators used in the instrument include: (1) introducing the story to be told; (2) the plot of the story; (3) skill in dialogues; (4) voice variation; (5) body movement and the props used. The data collection methods are methods used in collecting data, such as tests, interviews, observation, examination/test, and documentation (Arikunto, 2005, p. 101). The data in this research were collected through observation, documentation, and performance test of speaking skill. The data were in the form of the record of students' voice when doing storytelling, and the photographs of the students' storytelling performances.

The analysis of the data on an activity is in the form of the data analysis and interpretation aimed at positioning varieties of information in accordance with its function so as to give meaning to it (Sanjaya, 2016, p. 106). In this research, the data were analyzed qualitatively and quantitatively, that is to describe the achievement in learning how to tell a story by using hand puppets before and after treatment was given. The qualitative analysis was conducted to the data collected in the observation. While the quantitative analysis was conducted to analyze the students' storytelling skill before and after they were given treatment.

The performance test was administered to measure the result of students' speaking skill in Indonesian language learning. In order to reveal whether or not there was improvement in students' speaking skill, the researcher compared the result of the test administered at the end of each cycle.

The final result of the test was converted into a score by using the following formula:

$\mathrm{S}=\frac{R}{N} \times 100$

where:

$\mathrm{S}=$ the expected score (to be searched)

$\mathrm{R}=$ the sum of item scores (the score gained)

$\mathrm{N}=$ the maximum score of the test (Purwanto, 2011)

The quantitative score of the storytelling skill was obtained by comparing the total score of each indicator and the maximum score of storytelling skill. The indicator of success in students' storytelling skill is when the minimum performance achieved the score of $\geq 75$ or above. The final result to know the percentage of the category of class success in storytelling skill with storytelling performance and motivation using the questionnaire was obtained by using the following formula.

$\mathrm{p}=\mathrm{f} / \mathrm{N} \times 100 \%$

where:

$\mathrm{p}=$ the percentage

$\mathrm{f}=$ the frequency whose percentage is in question

$\mathrm{N}=$ number of classes (number of frequencies/individuals)

(Sudijono, 2005, p. 43)

The percentage of class mastery was obtained by counting the class average score. The use of hand puppets was considered successful when the mastery score of the whole class achieved $\geq 75 \%$ or above. When the result of the observation of each cycle had achieved the mastery level, the action stopped.

The analysis of documents in the form of photographs, videos, and teaching notes was conducted through the storytelling activities in each cycle. When the students were doing storytelling performance, the teacher and observer documented the performance in the form of photographs/pictures using a digital camera. The photographs were used for documenting the teaching activity and simultaneously used as evidence to fulfill the result of the research.

\section{Result and Discussion}

Cycle 1

Based on the initial condition of the school, there were facilities which could support the students' teaching-learning activities. The facilities that Muhammadiyah Elementary School Sapen has is quite adequate and all of them are in a good condition and feasible to use in teaching activities. The result of 
the initial observation of the students before the classroom action showed that the 30 students who took Bahasa Indonesia, particularly storytelling materials, did not have storytelling abilities. Problems arose when the students began to continue a story such as introducing the story, the story dialogues, voice improvisation, gestures, and facial mimic. There were three students (10\%) who could perform voice improvisation. The essential problem was the low volume voice. In terms of the aspect of the achievement in the storytelling media use, three students (10\%) were skillful at using media. They looked groggy in using storytelling media. Only six students (20\%) mastered the dialogues, while the rest seemed to think in doing dialogues. The story they told was poorly sequenced and they seemed to find it difficult to tell stories and they did not do it smoothly. They were not brave to tell stories in front of their friends; they were afraid of making mistakes, and they were shy, nervous, tensed, and unconfident when they were asked to tell stories in front of the class. The average score of performance before the action was 61 , which was below the expected minimum mastery of $\geq 75$.

With those data in mind, the researcher continued to collect data for the materials for reflection. The problems arose because there were students who were afraid, some were shy, some others were confused, and some had the feeling that they could not tell stories. In the teaching of Bahasa Indonesia, there were factors inhibiting storytelling skill, such as the teaching process which was teacher-centered. Another inhibiting factor was the minimum use of media in the classroom during the process of teaching Bahasa Indonesia.

From the result of the reflection above, the researcher in cooperation with the collaborator teacher designed Cycle 1 activities. The observation during the teaching process included students' interest in teacher's storytelling by using hand puppets, their activity in answering questions, and simple discussions about the story from the teacher. In the first meeting, the core activity became the main teaching point and it took 40 minutes. The presentation of the information began with the students listening to the teacher's explanation of the teaching-learning activity on that day. A few moments later, the students observed the picture in the student-book on page 31 guided by the teacher. Information was gathered through reading materials, and the students read aloud the learning materials of daily activities in the student-book on page 31. To enrich their vocabulary, the students and teacher asked each other about the vocabulary items in the reading materials. They listened to the teacher's explanation to work in six groups each consisting of 3-4 students. Then, they listened to and watched the hand puppet used by the teacher in conveying a story. They asked her anything not clear to them about the characters, plot of the story, and so on. In order to facilitate the students to understand the story, the teacher asked them the story she presented, which was about a good way of storytelling. The material presentation ended by giving them opportunities to play with hand puppets in their group..

In the second meeting which lasted 50 minutes, the students were asked to prepare themselves by way of practicing for 10 minutes. When they were ready, the teacher called them one by one based on the name of their group. They were given an opportunity to tell about their daily activities in 1-2 minutes by using hand puppets. They told the stories they prepared at home. They could show their creativity starting from introducing the story, characters, dialogue variation, voice, and the use of hand puppets. Meanwhile, the other groups listened to it. In the same occasion, the other groups responded to what their friends had presented in the storytelling activity.

After all of the students had finished storytelling, the teacher asked them to discuss by giving a question to some students who were below standard in storytelling. To motivate them to tell stories, the teacher gave a reward to the group which got the highest score.

Cycle 1 was conducted in two meetings. In the second meeting, the researcher did the observation of storytelling ability through storytelling performance. The average score of the students' storytelling skill performance test was 62.5 . The number of the students who achieved the minimum mastery was 12 students (40\%), while 18 students (60\%) did not achieve the minimum mastery. There was an average increase from 61 in the pre-action to 62.5. The Figure 1shows the increase in the students' storytelling skill in Cycle 1.

Figure 1 shows that the average mastery score of each storytelling skill aspect increased from precycle to Cycle 1, but each aspect had not achieved the target mastery. The following figure shows the increase of the average score of storytelling skill mastery. 
Jurnal Prima Edukasia, 8 (2), 2020 - 170

Siti Zuraidah, Kastam Syamsi, Ashadi Ashadi

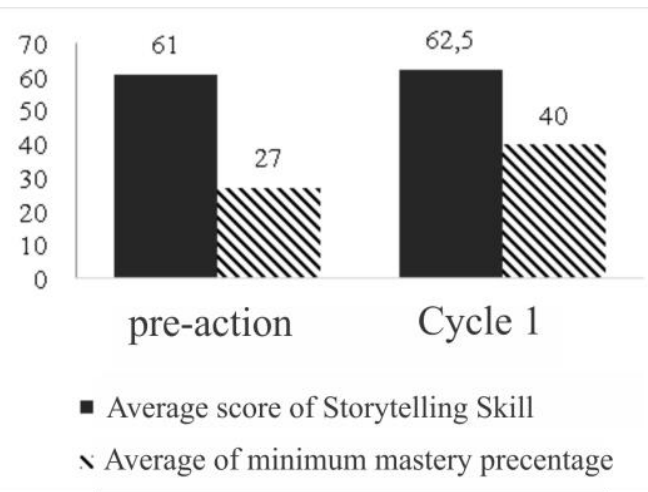

Figure Error! No text of specified style in document.1. Students' Storytelling Skill Keterampilan Bercerita Siswa Siklus I

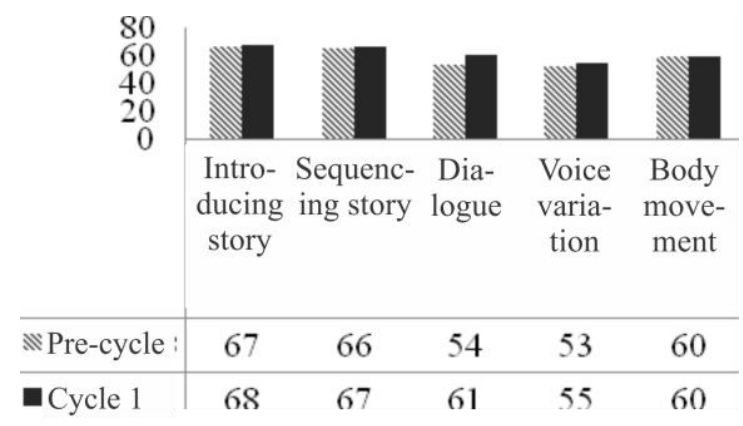

Figure 2. Average Score of Each Storytelling Skill Aspect before Cycle to Cycle I

Based on the Figure 2, the reflection on the aspect of storytelling skill aspect was conducted. The average score of the aspect of introducing stories reached 68. As many as $63 \%$ of the students mastered the aspect of introducing stories very well, which means that $37 \%$ of the students were not very good at presenting what they should introduce in their storytelling activity. For this reason, in the first meeting of Cycle 1, in the core activity the teacher had to repeat explaining and to emphasize on what elements should be presented in introducing a story. The elements consisted of the theme of the story, characters involving in it, and the characteristics of each character.

The average score of the aspect of sequencing stories reached 68 . The percentage of the mastery of the story sequencing aspect was $64 \%$, which means that $36 \%$ of the students were not very good at sequencing the story they told. When telling a story, the students did not sequence it and could not distinguish the main part from the introductory part of the story. In Cycle 2, at the main stage of her teaching, the teacher had to show the differences among the parts of a story, i.e. the introductory, main, and final parts as well as sequencing in storytelling. Telling a story sequentially and perspicuously would make it easy for the listeners to know its content.

The average score of the aspect of story dialogues reached 68 . The percentage of the mastery of the students' ability to act out dialogues was $63 \%$. This means that $37 \%$ of the students still had constraints in acting out dialogues. They were not maximum at choosing inter-sentential relation, and it resulted in uninteresting and monotonous dialogues. When they forgot the part of a dialogue they used fillers, "aaa, eee, what is it". To improve the students' ability to act out dialogues, in Cycle 2 the teacher had to explain and give concrete examples of how to act out dialogues in a story. The ability to perform dialogues included the use of words and sentences, differentiating characters' voices, and dialogues in certain situations. The appropriateness in performing dialogues in storytelling would make it easy for the listeners to understand the content of the story told by a storyteller.

The average score of the aspect of voice variation reached 55. The percentage of the mastery of the students' ability to use voice variation in storytelling was $33 \%$. The percentage of the students who did not have this ability was $67 \%$. The main constraints was that they could not differentiate voices in accordance with the characteristics of the characters. The pronunciation was often obscure and very frequently two characters did not have different voices, all of which demotivated other students to listen to the story teller. This skill had to be paid attention to by the teacher. In Cycle 2, the teacher could give opportunities to students to practice longer to improve their ability to vary their voice spontaneously, to 
pronounce clearly, and to distinguish characters' voices. She also had to give more examples in each group so that this aspect was easier to convey.

The average score of the aspect of body movement reached 60 . The percentage of the mastery of the use of body movement and media aspect was 53\%, which means that $47 \%$ of the students were not maximum using body gestures and hand puppets. The observable problem was that the students were in doubt and shy of expressing themselves. When storytelling in front of the class, they just stood still to tell a story without expression. The hand puppet was just held in their hand without playing it in accordance with the dialogue.

To improve the ability to use body movement and hand puppets, in Cycle 2 the teacher had to give a special guidance and a real life example of using body movement.

Cycle 2

Before Cycle 2 was conducted, there were several things done in relation to the conduct of cycles with regard to the result of the reflection of Cycle 1, where the result of the observation of students' storytelling skill performance showed that 12 students (40\%) achieved the target mastery. Thus, there were 18 students $(60 \%)$ who had not achieved the minimum mastery of $\geq 75$. Storytelling skill materials had to be emphasized, including the aspects of storytelling skill and storytelling techniques.

The core activity began with the students watching the video about an example of a child doing storytelling using a puppet media played by the teacher using a projector. The students listened to her explanation about how to introduce a story, story sequences, dialogues in the story, voice variation, and body movement and the media used in storytelling. At the same occasion, she also invited a student to story tell using a hand puppet. The teacher explained the aspect of motivation, particularly the perseverance and effort to make. The students paid attention to the story being told and were given opportunities to ask questions.

In 10 minutes the students practiced varieties of dialogues, voice variation in storytelling, body movement, and uses of hand puppets available in their school or those brought from home. The teacher observed the students whose scores in skill and storytelling motivation were below the stated average. The students' guidance was done by using easily understood language and simple but varied dialogues.

With the teacher's guidance, the students began to practice storytelling in front of the class. To motivate them to tell a story well, fluently, and creatively, she provided rewards. She added the allocated time in the lesson plans, including two meetings, each taking 35 minutes. At the same occasion, she also invited a student who was skillful at storytelling using hand puppets. The allocated time for the second meetings was four times 35 minutes ( 4 x $35^{\prime}$ ). In this way, the students could do storytelling performances within longer time.

In the main activity of the second meeting, the students practiced varieties of dialogues, voice variation in storytelling, body movement, and uses of hand puppets available in their school or those brought from home. The teacher guided them to tell a story using dialogues containing simple but varied vocabulary items within 10 minutes.

The students performed storytelling in front of the class using hand puppets. The teacher encouraged them to stand in front of the class self-confidently. They were called at random so that all of them were always ready. Each student was given three to four minutes to tell a story. The student who got the highest score got a reward from their teacher.

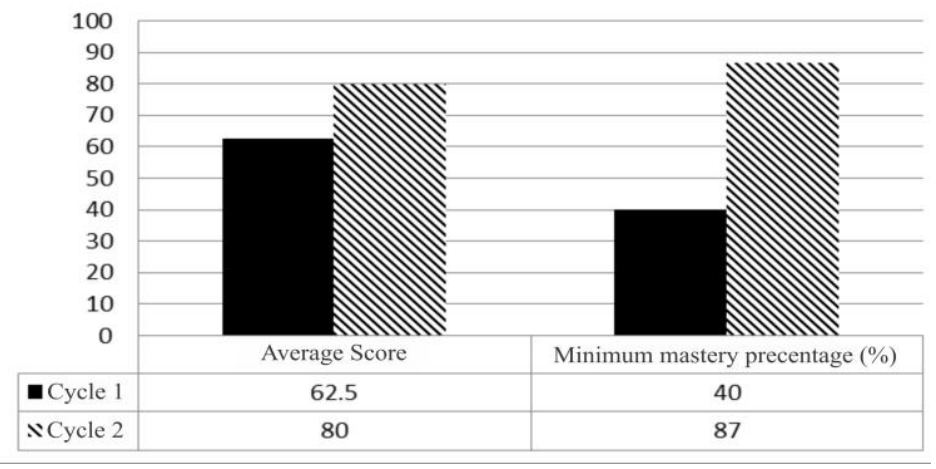

Figure 3. Average Score of Each Storytelling Skill Aspect before Cycle to Cycle I 
The result of the storytelling skill performance test in Cycle 2 increased. This can be seen in the average of the storytelling skill performance test score of 80 . The number of the students who achieved the minimum mastery was 26 students (87\%), while 2 students (4\%) was below minimum mastery level (Figure 3). There was an increase in the average score from 62.5 in Cycle 1 to 80 in Cycle 2.

In Cycle 1, 12 students (40\%) achieved the minimum mastery, and in Cycle 2 there was an increase with 26 students $(87 \%)$ achieving minimum mastery. The following figure shows six scores which increased from Cycle 1 to Cycle 2.

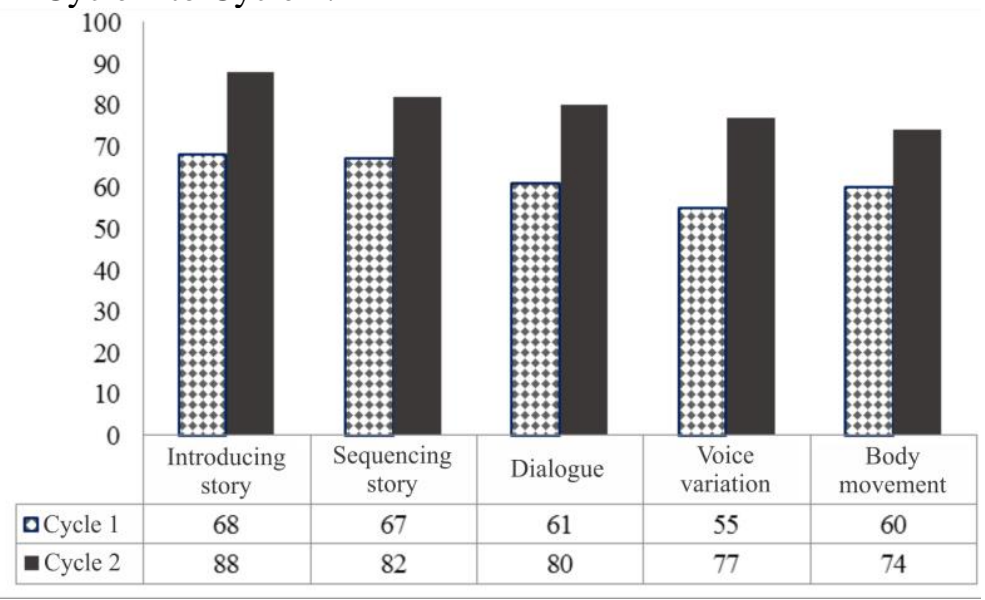

Figure 4. Increase of Average Storytelling Skill Scores from Cycle I to Cycle II

Figure 4 shows that in Cycle 2, the total sum of storytelling skill average score is 80 . This score is above the stated minimum mastery of $\geq 75$. The number of students who achieved the minimum mastery is 26 (86\%), which is an increase from 12 students (40\%) in Cycle 1. Meanwhile, the average score of each aspect of storytelling skill is $\geq 75$. In accordance with the graph of storytelling skill above, the researcher did the reflection based on the storytelling skill aspect.

The average score of introducing a story in Cycle 2s 68 and in Cycle 2 is 88 . In the first meeting of Cycle 1, the teacher explained only the aspect that had to be mentioned when introducing a story. The increased score of 88 happened because at the action stage of Cycle 2, the teacher put the emphasis on all of the aspects introduced before telling a story. She wrote those aspects on the board and gave examples directly to the students.

The skill in introducing a story could be seen when the students could mention/tell the story sequentially, starting from greeting, introduction, till the end. For example: the title of the story, the main theme, the characters, and the characteristics of the characters. This ability is a proof that the students have the ability to communicate concisely, as the introduction to the story which will be told. Storytelling functions as a means of learning which can encourage students to explore expression and improve their ability to communicate their thought and feeling perspicuously (Mokhtar et al., 2011).

Figure 4 also shows that the average score of the aspect of story sequencing in Cycle 2 is 67 , increasing to 82 in Cycle 2. This increase was shown by 28 students (93\%), an increase from 19 students (64\%) in Cycle 1. When telling a story, the students could distinguish the main part from the introductory part of the story sequentially. In the first meeting of Cycle 1, they looked at the pictures in the studentbook with teacher guidance. Information was gathered from reading materials, and they read aloud learning materials about daily activities in the student-book at home. In the main activity of Cycle 2, the teacher explained the differences among parts of a story, including the introductory, core, and final parts of the story. They could achieve the criteria although some still seemed to memorize the sequence.

The sequence of a story or often known as the storyline functions as a reminder which facilitates storytelling. The teacher should prepare a clear storyline (Santosa, 2008, pp. 38-39). Fluency in conveying a story will help a storyteller convey the content of the story coherently and fluently so that the listeners will be enthusiastic and interested in listening to the story being told (Garzotto et al., 2010, p. 356).

Performing dialogues in storytelling activities is an activity of mixing and inserting interesting phrases in a story. The resulting score of the dialogue aspect in Cycle 1 reached 61, while in Cycle 2 it reached a score of 80 . The percentage of the story dialogue aspect saw an increase. In Cycle 1, 19 
students (63\%) could act out dialogues, while in Cycle 2, 27 students (90\%) could do that. They seemed to get used to making improvisation of dialogues calmly in accordance with the situation in the story; they did not seem to memorize hard, and their pronunciation was good. The listeners became more enthusiastic to listen to the story. In Cycle 1, the teacher gave an example of storytelling using hand puppets. In Cycle 2, she explained and gave concrete examples of the way to act out dialogues in a story. The ability to perform dialogues consisted of the use of words and sentences, differentiating voices of different characters, and inserting dialogues in certain situations. The teacher played the video about storytelling lesson.

The students who have the dialoguing skill seem to get used to using figure of speech which is used to attract the audience attention (Miller \& Pennycuff, 2008). Oral practice through storytelling improves the speaking and oral communication skills related to pronunciation and articulation. An interesting and motivating story will attract audience and promote communication. The relax situation resulted from a story encourages students to talk and discuss with each other (Harriott \& Martin, 2004).

Voice variation is shown by the ability to use different voices of the characters in a story in accordance with their characteristics, including clear pronunciation and vocal expression variation. In this research, the aspect of voice variation has achieved the target score. The average score of voice variation aspect in Cycle 2 was 55, which increased to 77 in Cycle 2. In Cycle 1 only 10 students (33\%) had the skill in using varied voices, while in Cycle 2 the number increased to 24 students (80\%). In Cycle 1, the teacher did not give the students the opportunity to practice storytelling due to the limited allocated time. In Cycle 2, at the planning stage she prolonged the allocated time to give students the opportunity to have more practice. As a result, they had the skill in varying voices spontaneously, pronouncing clearly, and distinguishing voices of different characters. In addition, she also invited a storyteller student to the class, who gave examples of how to tell a story, so that this aspect was more easily conveyed.

Imitating sounds has a direct effect on vocabulary development which is the result of listening to stories. The research on pre-school and year-one students reported that a systematic story recited in loud voice will develop the habit of listening and at the same time also give special comprehension skill through the interesting exposure of the content of the story and language production (Al-Mansour \& AlShorman, 2011).

What is meant by body movement is how students move their body and hands when they are telling a story, including running forward and akimbo. The term media used here refers to hand puppet which is an aid used in storytelling. In this study, the aspects of body movement and media achieved the target score. The average score of this aspect in Cycle 1 reached 60, which increased to 74 in Cycle 2. Most of the students used hand puppets and body movement, and some even used bloking and floor balls. In Cycle 1, only 16 students (53\%) had the skill in this aspect. In Cycle 2 the number increased to 23 students (77\%). In Cycle 1, the teacher classically gave examples of how to use gestures and hand puppets. In Cycle 2 she had to give a special guidance and gave real-life example of using body gesture by using a hand puppet.

As a strong symbolic media, a puppet facilitates students to express emotion, solve problems, and express emotion to themselves. It helps teachers to understand their students more easily and to identify their feelings and problems, and it enables quicker achievement of curricular objectives which are more interesting (Agofure, 2016). Body movement indicates interest and attention, and involves the negotiation of communication and mutual understanding. The meaning arises spontaneously through students' repeated movement and imagination (Daniels, 2020, p. 10).

The available simple puppets can give opportunities to students to develop their dramatic creativity and skill simultaneously. They can be used not only in drama activities, but also as a way to develop language skill (Tompkins, 2002). The average score of the aspect of introducing story reached 88. In this Cycle 2, all of the students mastered the aspect of introducing story well. They could mention the title of the story, the characters involving in it, and its theme. In the first meeting of Cycle 2, at the main stage the teacher emphasized on the way to introduce stories.

The result of the storytelling skill performance showed that 26 out of 30 students showed an increase and achieved the minimum mastery level, while four students did not. The average achievement score in Cycle 2 was 80, with the percentage of minimum mastery of $80 \%$. This result also shows the stated target of $\geq 75 \%$, and thus this research stopped after Cycle 2 . 
In elementary school teaching, storytelling is not a strange activity for the students. With reference to the Basic Competence in the content standard of Curriculum 2013, storytelling activities are developed in students of lower classes focusing on free stories about self. However, in reality when the teacher asked the students to tell a story, few students voluntarily and bravely came forward to tell a story in front of the class. They even pointed at other students to do it. This brought about their low storytelling skill. Research findings show that there are some classic problems in the implementation of storytelling activities, i.e. most students did not want to tell about themselves, they preferred to give judgment and to talk about their experience in school, and they could not write texts well (Hyland, 2018).

The result of the pre-research observation conducted by the researcher and collaborator teacher during the process of the teaching of Bahasa Indonesia showed that when storytelling activities were done in the first meeting, the teacher only asked the students to read the example of stories in the textbook. She explained briefly how to perform a good storytelling, without giving real life examples. The students were asked only to mention one of the titles of the stories on television and to remember the storyline. At the end of the main activity she invited them to discuss the aspects in a good story.

Such a teaching model above will hinder the teaching objective in terms of the material load. The students tended to play with each other and they seemed to be uninterested in what the teacher explained. When asked to mention the aspects in a story, they could just give a short answer.

The storytelling skill is very important for elementary school students. It is taught as one of subspeaking skills in the teaching of Bahasa Indonesia. The teaching of storytelling to grade I students of course begins with simple words and sentences in accordance with grade I students' characteristics. The scope of the story begins with the surrounding environment close to them. Storytelling is considered as a method which can be applied in lower class instruction because young students enjoy the recital of stories like tales. Storytelling is very effective in conveying the values of education and knowledge (Halidjah \& Magiyati, 2018).

Storytelling activities can be done based on stimuli. The materials used as the source of the story include storytelling based on varieties of stories (fiction and legend), daily experience, and books or the stories which are read (Nurgiyantoro, 1988, p. 451).

In Theme 4 entitled My Family, there is a basic competency stating. "Telling activities in accordance with the rules in daily life at home" with the indicators of achievement being the ability to tell daily home activities by students.

The storytelling skill of grade I students of Al Ibadi Class of Muhammadiyah Elementary School Sapen was developed through the activities of telling students' daily activities in accordance with the rules imposed in daily life at home assisted by hand puppet media. The choice of an appropriate media can enhance students' interest in the materials presented by the teacher.

The hand puppet used in the teaching of storytelling to lower class students can stimulate them to think critically, express their opinions, make them focus on teaching processes so that by their being focused on the teaching materials presented by their teacher they will be motivated to move around, ask questions, and talk to the hand puppet (Caganaga \& Kalmis, 2015, pp. 7-8).

The hand puppet utilized in teaching can motivate students to tell a story in front of the class. Their self-confidence emerges naturally when they express ideas in the story. Children use hand puppets to express what they have in mind. Hand puppets motivate them to use language (Nurbianti, 2005). There are five uses of hand puppets: making communication smooth, enlivening classroom teaching condition, increasing creativity, encouraging group work, and improving character (Kröger \& Nupponen, 2019). Hand puppets can improve children's ability in various aspects, including their cognitive, emotional, and social relation aspects. They facilitate teaching processes (Remer \& Tzuriel, 2015, p. 356).

The developing self-confidence arouse the story atmosphere, which is firstly difficult to digest, to become interesting for other students to enjoy. In this research, the theme of daily activities was presented by the students more clearly. One of the functions of teaching media is to explain teaching materials or abstract objects to be concrete, to give real life and direct experience because the students can communicate with their learning environment (Sumiati, 2009, pp. 163-165).

In developing a story, the students encourage involvement, produce understanding or changes, and develop storytelling ability. Puppets become a means of discovering students' voice identity, collaboration, problem solution, innovation, and new comprehension. The students involving in puppet games naturally enliven puppets, figure and movement, and voice (Romanski, 2019, p. 172). 
Furthermore, puppets are transdisciplinary; they can be used in varieties of fields of study to discover meanings beyond each school subject. The transdisciplinary approach to the curriculum has the potential to create transformative learning environment which enables the learning initiated by students (Romanski, 2016, 2019, pp. 41-42).

\section{Conclusion}

The use of hand puppet media in the process of teaching Bahasa Indonesia can improve the storytelling skill of grade I students of Al Ibadi class of Muhammadiyah Elementary School Sapen, Yogyakarta. This can be seen in the students' increasing ability when they tell a story, which is their ability to introduce the story, including the title, theme, characters, and characters' characteristics. Their ability to manipulate dialogues can be seen when they could choose the relation among sentences, so that the dialogues looked interesting and not monotonous. The students' increasing skill in the aspect of story sequencing was evidenced when they could distinguish the main part from the introductory part of a story. They could differentiate the voices of different characters. In terms of voice variation, their pronunciation became clearer so as to motivate other students to listen to them. They became selfconfident in using expressive body movement when storytelling.

The data show improvement in the students' storytelling skill. In Cycle 1, the average score of storytelling skill was 62, which increased to 80 in Cycle 2. The percentage of class minimum mastery of storytelling skill increased from $40 \%$ in Cycle 1 to $87 \%$ in Cycle 2.

Based on the above conclusion, some suggestions are proposed as follows. Firstly, teachers are expected to use appropriate media in the process of teaching Bahasa Indonesia, especially on the materials related to speaking skill. Secondly, teachers are expected to give to their colleagues their experience that the use of hand puppets can improve the motivation and storytelling skill of elementary school students. Thirdly, a hand puppet is expected to be one of the alternative media in the teaching of Bahasa Indonesia in the effort to improve students' language competence. Fourthly, this study is expected to give insights into increasing innovation and creativity in teaching processes, especially in improving students' language skill by using hand puppets. Finally, this study was conducted in one class only, future studies can be developed by comparing some classes using the techniques such as peer tutors and by involving student parents at home.

\section{References}

Agofure, J. (2016). Puppet-performed show into theatre-in-education and the child development: A theoretical overview. Franklin Business \& Law Journal, 3, 128-145.

Al-Mansour, N. S., \& Al-Shorman, R. A. (2011). The effect of teacher's storytelling aloud on the reading comprehension of Saudi elementary stage students. Journal of King Saud University Languages and Translation. https://doi.org/10.1016/j.jksult.2011.04.001

Arikunto, S. (2005). Manajemen penelitian. Rineka Cipta.

Caganaga, C. K., \& Kalmis, A. (2015). The role of puppets in kindergarten education in Cyprus. OALib, 02(07), 1-9. https://doi.org/10.4236/oalib.1101647

Daniels, K. D. (2020). Moving hands in classroom assemblages: puppet play in a post-world. English Teaching: Practice \& Critique, ahead-of-p(ahead-of-print). https://doi.org/10.1108/ETPC-112019-0143

Daryanto, D. (2013). Media pembelajaran: Peranannya sangat penting dalam mencapai tujuan pembelajaran. Gava Media.

Dunlap, L. L. (2009). An introduction to early childhood special education : Birth to age five. Merrill/Pearson.

Garzotto, F., Paolini, P., \& Sabiescu, A. (2010). Interactive storytelling for children. Proceedings of the 9th International Conference on Interaction Design and Children -IDC '10, 356. https://doi.org/10.1145/1810543.1810613

Halidjah, S., \& Magiyati, M. (2018). Peningkatan keterampilan berbicara menggunakan metode bercerita pada siswa kelas III Sekolah Dasar Negeri 29 Sungai Ambawang. Jurnal Pendidikan Dan Pembelajaran Khatulistiwa, 7(4), 1-12. 
Jurnal Prima Edukasia, 8 (2), 2020 - 176

Siti Zuraidah, Kastam Syamsi, Ashadi Ashadi

https://jurnal.untan.ac.id/index.php/jpdpb/article/view/25179

Harriott, W. A., \& Martin, S. S. (2004). Using culturally responsive activities to promote social competence and classroom community. TEACHING Exceptional Children, 37(1), 48-54. https://doi.org/10.1177/004005990403700106

Hong, Y. (2012). Collaborative story telling through tangible technology.

Hyland, K. (2018). Metadiscourse: Exploring interaction in writing. Bloomsbury Publishing.

Kröger, T., \& Nupponen, A.-M. (2019). Puppet as a pedagogical tool: A literature review. International Electronic Journal of Elementary Education, 11(4), 393-401. https://www.iejee.com/index.php/IEJEE/article/view/688

Miller, S., \& Pennycuff, L. (2008). The power of story: Using storytelling to improve literacy learning. Journal of Cross-Disciplinary Perspectives in Education, 1(1), 36-43.

Mokhtar, N. H., Halim, M. F. A., \& Kamarulzaman, S. Z. S. (2011). The effectiveness of storytelling in enhancing communicative skills. Procedia - Social and Behavioral Sciences, 18, 163-169. https://doi.org/10.1016/j.sbspro.2011.05.024

Musfiroh, T. (2008). Memilih, menyusun, dan menyajikan cerita untuk anak usia dini. Tiara Wacana.

Nurbianti, D. (2005). Metode pengembangan bahasa. Universitas Terbuka Press.

Nurgiyantoro, B. (1988). Penilaian dalam pengajaran bahasa dan sastra. BPFE.

Petersen, K. S. (2014). Interviews as intraviews: A hand puppet approach to studying processes of inclusion and exclusion among children in kindergarten. Reconceptualizing Educational Research Methodology, 5(1). https://doi.org/10.7577/rerm.995

Purwanto, N. (2011). Evaluasi hasil belajar. Pustaka Pelajar.

Remer, R., \& Tzuriel, D. (2015). "I teach better with the puppet"-Use of puppet as a mediating tool in kindergarten education-an evaluation. American Journal of Educational Research, 3(3), 356365. https://doi.org/10.12691/education-3-3-15

Romanski, N. M. (2016). Narrative discourse in teaching practice: Uncovering multiple layers of story in the art classroom and implications for narrative leadership. In Dissertation Abstracts International Section A: Humanities and Social Sciences.

Romanski, N. M. (2019). Reigniting the transformative power of puppets through narrative pedagogy, contemporary art, and transdisciplinary approaches in art education. Art Education, 72(4), 3642. https://doi.org/10.1080/00043125.2019.1602496

Sadiku, L. M. (2015). The importance of four skills reading, speaking, writing, listening in a lesson hour. European Journal of Language and Literature, 1(1), 29. https://doi.org/10.26417/ejls.v1i1.p29-31

Sanjaya, W. (2016). Strategi pembelajaran berorientasi standar proses pendidikan. Prenada Media. https://doi.org/2008

Santosa, P. (2008). Materi dan pembelajaran Bahasa Indonesia SD. Universitas Terbuka Press.

Sudijono, A. (2005). Pengantar statistik pendidikan. PT Raja Grafindo Persada.

Sumiati, A. (2009). Metode pembelajaran. Bandung: Wacana Prima.

Tompkins, G. E. (2002). Language arts: Content and teaching strategies. Merrill/Prentice Hall.

Warso, A. W. D. D. (2017). Publikasi ilmiah tinjauan ilmiah dan best practice. Penerbit Graha Cendekia. 